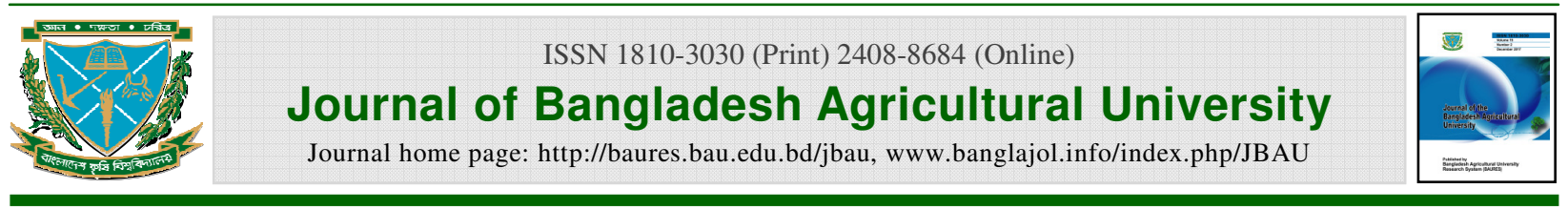

\title{
Effect of sulphur on the seed yield and oil content of sesame (Sesamum indicum $\mathbf{L}$.)
}

\author{
${ }^{凶}$ Swapan Kumar Paul, Mosa. Morsheda Khatun and Md. Abdur Rahman Sarkar
}

Department of Agronomy, Bangladesh Agricultural University, Mymensingh-2202, Bangladesh

\begin{tabular}{|c|c|}
\hline ARTICLE INFO OPEN $\odot A$ & $P$ \\
\hline $\begin{array}{l}\text { ticle history: } \\
\text { ceived : 01 January } 2019 \\
\text { ceepted : } 19 \text { February } 2019 \\
\text { blished: } 31 \text { March } 2019\end{array}$ & \multirow{3}{*}{ 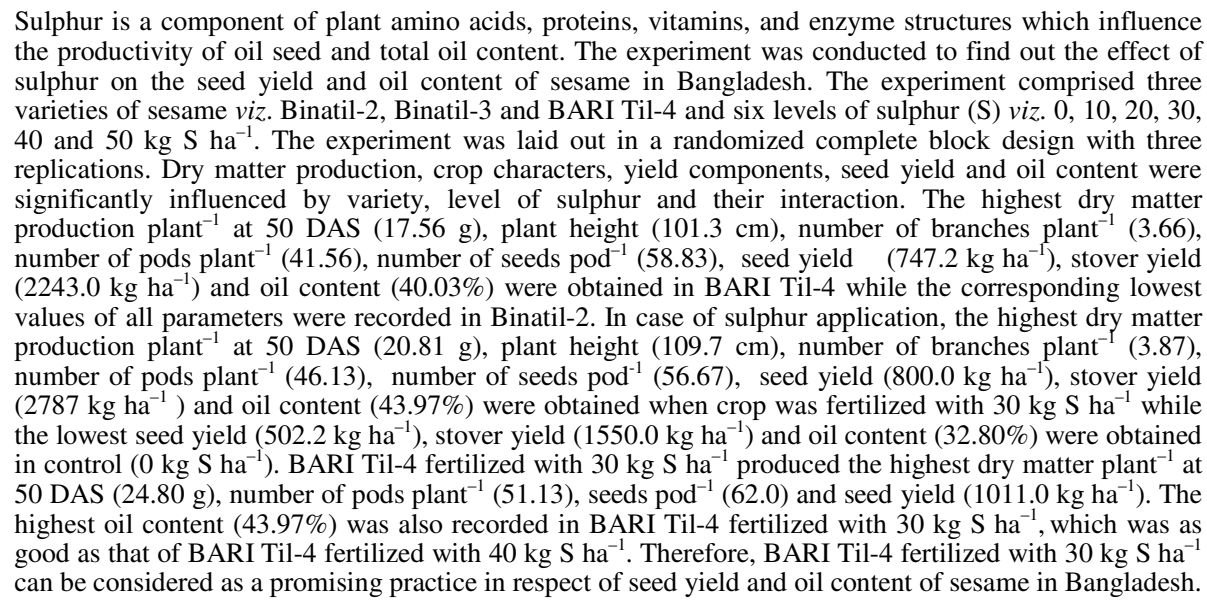 } \\
\hline $\begin{array}{l}\text { Variety, sulphur, } \\
\text { content, sesame }\end{array}$ & \\
\hline & \\
\hline
\end{tabular}

Copyright:

(c) (i)

(O2019 by authors and BAURES. This work is licensed under the Creative Commons Attribution International License (CC By 4.0).

\section{Introduction}

Sesame (Sesamum indicum L.) is one of the most ancient oil seed crops of the family Pedaliaceae. Its major production areas are the tropics and the subtropics of Asia, East and Central America. Sesame is cultivated all over Bangladesh but major growing districts are Pabna, Khulna, Faridpur, Rajshahi, Dhaka, Jessore and Mymensingh. Due to high competition among different high valued crops over the years, the acreage and production of sesame have severely decreased in recent years. The area under sesame cultivation was 3454 ha and a total production of 2970 metric tons was recorded in Bangladesh (BBS, 2015). Sesame is a versatile crop giving high quality edible oil. The oilseeds are very important because of its capability of synthesis of sulphur containing amino acids, vitamins, and constituent in human dietary system next to carbohydrates, protein and fats (Mohsana, 2009). Sesame has the highest oil content of $42-50 \%$ along with $25 \%$ protein compare to other oilseed crops. The sesame oil contains $16-18 \%$ carbohydrate and $42 \%$ essential linoleic acid (Miah et al., 2015), and the high grades of sesame oil are used for cooking, margarine manufacturing and in pharmaceutical industries (El
Naim et al., 2012). Its oilcake is a noble feed for poultry, fish, cattle, goat and sheep (Khan et al., 2009).

Sesame is a short duration photoinsensitive crop with wider adaptability. It can be cultivated both in Kharif-I (mid-February to mid-April) and Kharif-II (mid-August to mid-September) seasons. In Bangladesh, yield of sesame per unit area is very low $\left(0.92 \mathrm{t} \mathrm{ha}^{-1}\right)$ (BBS, 2017) compared to other sesame producing countries of the world. The main reasons for poor yield are lack of suitable varieties and improper management practices. Variety plays an important role on the yield and quality of sesame. Seed yield variations due to varietal potentiality have already been reported (Mohsana, 2009; Raja et al., 2007). Akinoso et al. (2010) noticed that the brown seeded strain contains higher oil than black seed. In addition, best quality edible oil and as well as medicinal oil can be extracted from sesame that can be preserve for a long period of time.

Sulphur is an essential element for plant growth particularly for oilseed crops which play an important role in plant metabolism system, crucial for the synthesis of essential oil that plays a key role in formation of chlorophyll in plant leaf (Ajai et al., 2000), increase cold 
and drought resistance ability in plant (Patel and Shelke, 1995). It also increases oil content and pungency in oil (Khan et al., 2016). Oil crops are sulphur (S) loving and $S$ plays a vital role in the plant metabolism thus increasing a number of organic compounds, oil storages, particularly oil glands and vitamin $\mathrm{B}_{1}$ (Shelke et al., 2014). Sulphur is a constituent of three essential amino acids commonly found in plants, namely cysteine and methionine, which are essential components of proteins. It can be called as master nutrient for oil seed production. Application of $40 \mathrm{~kg} \mathrm{~S}(20 \mathrm{~kg}$ basal $+20 \mathrm{~kg}$ at 20 days after sowing (DAS)) along with NPK significantly increased yield of sesame (Kundu et al., 2010). Nagwani et al. (2001) and Sarkar and Banik (2002) reported that yield of sesame increased up to application of $30 \mathrm{~kg} \mathrm{~S} \mathrm{ha}^{-1}$ and $50 \mathrm{~kg} \mathrm{~S} \mathrm{ha}{ }^{-1}$, respectively. Sulphur application increased seed yield as well as oil quality of sesame (Tiwari and Gupta, 2006). Hence, the present study was undertaken to study the effect of sulphur on the growth, yield and oil content of three sesame varieties.

\section{Materials and Methods}

The experiment was conducted at the Agronomy Field Laboratory, Bangladesh Agricultural University, Mymensingh during March to June 2016. The experimental site was located at $24.7^{\circ} \mathrm{N}$ latitude and $90.50^{\circ} \mathrm{E}$ longitude with an altitude of $18 \mathrm{~m}$ above the mean sea level. The research field belongs to the agroecological zone of the Old Brahmaputra Floodplain (AEZ-9). The soil of the research field belongs to the Sonatola series of non-calcareous dark grey floodplain soil. The experiment comprised three popular sesame varieties viz. Binatil-2 $\left(\mathrm{V}_{1}\right)$, Binatil-3 $\left(\mathrm{V}_{2}\right)$ and BARI Til-4 $\left(\mathrm{V}_{3}\right)$ and six sulphur $(\mathrm{S})$ levels viz. $0\left(\mathrm{~S}_{0}\right), 10\left(\mathrm{~S}_{10}\right)$, $20\left(\mathrm{~S}_{20}\right), 30\left(\mathrm{~S}_{30}\right), 40\left(\mathrm{~S}_{40}\right)$ and $50\left(\mathrm{~S}_{50}\right) \mathrm{kg} \mathrm{S} \mathrm{ha}^{-1}$. The experiment was laid out in a randomized complete block design with three replications. The experimental unit was divided into 3 blocks with 18 unit plots of size 5.0 $\mathrm{m} \times 2.0 \mathrm{~m}$ in each block. The land was prepared by ploughing and cross ploughing with country plough followed by laddering. The corner of the land was spaded and visible large clods were broken into small pieces. Weeds and stubble were removed from the field. The layout of the experiment was done in accordance with the design adopted. The crop was fertilized with $120 \mathrm{~kg}$ urea $\mathrm{ha}^{-1}, 140 \mathrm{~kg}$ triple super phosphate (TSP) $\mathrm{ha}^{-1}, 70 \mathrm{~kg}$ muriate of potash (MoP) ha ${ }^{-1}, 2.5 \mathrm{~kg}$ zincoxide $(\mathrm{ZnO}) \mathrm{ha}^{-1}$. Gypsum was used as source of $\mathrm{S}$ as per treatment specification. The whole amount of TSP, $\mathrm{MOP}, \mathrm{ZnO}, 50 \%$ of urea and required amount of gypsum were applied at final land preparation. The remaining urea was applied at 25 days after seed germination. Seeds of sesame $\left(6 \mathrm{~kg} \mathrm{ha}^{-1}\right)$ were sown in $25 \mathrm{~cm}$ apart rows on 10 March 2016 in 2-3 cm deep furrows made by hand rake. After establishment, the crop was thinned by keeping only healthy seedling at 5 $\mathrm{cm}$ distance in each row. Two hand weeding were done at 20 and 45 days after sowing (DAS). The crop was infested with hopper (Heliothis armigera) at the reproductive stage, which was successfully controlled by spraying insecticide Limida $17.8 \% \mathrm{SL}$ at the rate of $3.375 \mathrm{ml} 10 \mathrm{~L}^{-1}$ of water.

To measure dry matter production plant ${ }^{-1}$, five plants were randomly uprooted at 50 DAS (excluding border rows and central $1 \mathrm{~m} \times 1 \mathrm{~m}$ harvest area), and oven dried until constant weight was reached. At harvest, five sample plants plot $^{-1}$ were collected (excluding boarder row and central $1 \mathrm{~m}^{2}$ ) to record data on yield components. Central $1 \mathrm{~m}^{2}$ area in each plot was harvested, threshed and seeds and stover were sun dried and weighed to record the yield in $\mathrm{kg} \mathrm{ha}^{-1}$. The oil content was estimated by Soxhlet apparatus method following the procedure of Singh et al. (1960). The collected data were analyzed statistically using "Analysis of Variance" with MSTATC computer programm and the difference among treatment means were adjudged by Duncan's Multiple Range Test (DMRT) (Gomez and Gomez, 1984).

\section{Results and Discussion}

\section{Effect of variety}

Variety exerted a positive effect on dry matter production, yield components, seed yield and oil content of sesame (Table 1). BARI Til-4 produced the highest dry matter $(17.56 \mathrm{~g})$ followed by Binatil-3 (12.93 g) and the lowest dry matter was produced in Binatil-2 (10.53 $\mathrm{g})$. The tallest plant $(101.3 \mathrm{~cm})$ was found in BARI Til-4 which was at par with Binatil-3 $(99.34 \mathrm{~cm})$ and the shortest one $(94.63 \mathrm{~cm})$ was recorded in Binatil-2. BARI Til-4 produced the highest number of branches plant ${ }^{-1}$ (3.6), number of pods plant ${ }^{-1}$ (41.56) and number of seeds $\operatorname{pod}^{-1}$ (58.83) followed by Binatil-3 and their corresponding lowest values of all characters was found in Binatil-2. The highest 1000-seed weight ( $2.94 \mathrm{~g})$ was found in Binatil-2 and the lowest one $(2.61 \mathrm{~g})$ was recorded in BARI Til-4 which was at par with Binatil-3 (Table 1). BARI Til-4 produced the highest seed yield $\left(747.20 \mathrm{~kg} \mathrm{ha}^{-1}\right.$ ) followed by Binatil-3 and Binatil-2. The highest number of branches plant ${ }^{-1}$, pods plant $^{-1}$ and seeds pod $^{-1}$ contributed to the highest seed yield in BARI Til-4 compared to other varieties. Akinoso et al. (2010) reported that variety played an important role on the seed yield of sesame. The highest stover yield $\left(2243.00 \mathrm{~kg} \mathrm{ha}^{-1}\right)$ was recorded in the variety BARI Til4 followed by Binatil-3 and the lowest one was recorded in Binatil-2. The highest harvest index $(25.48 \%)$ was obtained in BARI Til-4 which was at par with Binatil-2 $(24.66 \%)$ and the lowest harvest index was found in Binatil-3 (22.95\%). Oil content was also significantly influenced by variety. The highest oil content was obtained in BARI Til-4 (40.03\%) followed by Binatil-3 $(38.82 \%)$ and the lowest one (37.45\%) was recorded in Binatil-2 (Table 1). 
Table 1. Effect of variety on dry matter production, crop characters, yield components, seed yield and oil content of sesame

\begin{tabular}{|c|c|c|c|c|c|c|c|c|c|c|}
\hline Variety & $\begin{array}{c}\text { Dry matter } \\
\text { production plant }^{-1} \\
\text { at } 50 \text { DAS }(\mathrm{g})\end{array}$ & $\begin{array}{l}\text { Plant height } \\
\text { at harvest } \\
(\mathrm{cm})\end{array}$ & $\begin{array}{l}\text { No. of } \\
\text { branches } \\
\text { plant }^{-1}\end{array}$ & $\begin{array}{l}\text { No. of } \\
\text { pods } \\
\text { plant }^{-1}\end{array}$ & $\begin{array}{l}\text { No. of } \\
\text { seeds } \\
\text { pod }^{-1}\end{array}$ & $\begin{array}{l}\text { 1000- seed } \\
\text { weight } \\
(\mathrm{g})\end{array}$ & $\begin{array}{c}\text { Seed } \\
\text { yield } \\
\left(\mathrm{kg} \mathrm{ha}^{-1}\right)\end{array}$ & $\begin{array}{c}\text { Stover } \\
\text { yield } \\
\left(\mathrm{kg} \mathrm{ha}^{-1}\right)\end{array}$ & $\begin{array}{c}\text { Harvest } \\
\text { index } \\
(\%)\end{array}$ & $\begin{array}{c}\text { Oil } \\
\text { content } \\
(\%)\end{array}$ \\
\hline Binatil-2 & $10.53 c$ & $94.63 b$ & $3.37 \mathrm{~b}$ & $34.56 c$ & $44.50 \mathrm{c}$ & $2.94 \mathrm{a}$ & $548.3 c$ & $1716.00 \mathrm{c}$ & $24.66 a$ & $37.45 \mathrm{c}$ \\
\hline Binatil-3 & $12.93 b$ & $99.34 \mathrm{a}$ & $3.41 \mathrm{~b}$ & $39.48 b$ & $53.83 b$ & $2.70 \mathrm{~b}$ & $591.2 b$ & $1950.00 \mathrm{~b}$ & $22.95 b$ & $38.82 b$ \\
\hline BARI Til-4 & $17.56 \mathrm{a}$ & $101.3 \mathrm{a}$ & $3.66 \mathrm{a}$ & $41.56 \mathrm{a}$ & $58.83 a$ & $2.61 b$ & $747.2 \mathrm{a}$ & $2243.00 \mathrm{a}$ & $25.48 \mathrm{a}$ & $40.03 \mathrm{a}$ \\
\hline$S \bar{x}$ & 0.192 & 0.719 & 0.055 & 0.485 & 0.470 & 0.038 & 14.18 & 35.00 & 0.288 & 0.213 \\
\hline $\begin{array}{l}\text { Level of } \\
\text { significance }\end{array}$ & $* *$ & $* *$ & $* *$ & $* *$ & $* *$ & $* *$ & $* *$ & $* *$ & $* *$ & $* *$ \\
\hline $\mathrm{CV}(\%)$ & 5.97 & 3.10 & 6.73 & 5.35 & 3.81 & 5.58 & 9.56 & 7.54 & 5.03 & 2.33 \\
\hline
\end{tabular}

In a column, figures with same letter or without letter do not differ significantly whereas figures with dissimilar letter (s) differ significantly (as per DMRT).

$* *=$ Significant at $1 \%$ level of probability

\section{Effect of sulphur level}

Dry matter production, plant height, number of branches plant $^{-1}$ and number of seeds pod ${ }^{-1}$ were significantly influenced by $S$ levels (Table 2). Results revealed that all the above mentioned characters were increased up to $30 \mathrm{~kg} \mathrm{~S} \mathrm{ha}{ }^{-1}$ and thereafter declined. The highest dry matter production plant ${ }^{-1}(20.81 \mathrm{~g})$ was obtained from $30 \mathrm{~kg} \mathrm{~S} \mathrm{ha}^{-1}$ followed by (16.31 g) $40 \mathrm{~kg} \mathrm{~S} \mathrm{ha}^{-1}$ and the lowest one $(8.748 \mathrm{~g})$ from $0 \mathrm{~kg} \mathrm{~S} \mathrm{ha}^{-1}$. Sharma and Gupta (2003) also reported increased dry matter accumulation in sesame with application of $\mathrm{S}$ at $40 \mathrm{~kg}$ $\mathrm{ha}^{-1}$. The tallest plant $(109.7 \mathrm{~cm})$ was found in $30 \mathrm{~kg} \mathrm{~S}$ $\mathrm{ha}^{-1}$ followed by $40 \mathrm{~kg} \mathrm{~S}^{-1}$, which was as good as 50 $\mathrm{kg} \mathrm{Sha}^{-1}$ and the lowest one was recorded in $0 \mathrm{~kg} \mathrm{~S} \mathrm{ha}^{-1}$ (Table 2). Obaidul (2012) reported that plant height was significantly affected by different $\mathrm{S}$ levels. The highest number of branches plant ${ }^{-1}(3.86)$ was obtained in $30 \mathrm{~kg}$ $\mathrm{S} \mathrm{ha}^{-1}$ which was at par with $40 \mathrm{~kg} \mathrm{~S} \mathrm{ha}^{-1}$ and the lowest one (2.93) in control treatment $\left(0 \mathrm{~kg} \mathrm{~S} \mathrm{ha}^{-1}\right)$. The highest number of pods plant ${ }^{-1}$ (46.13) was recorded in $30 \mathrm{~kg} \mathrm{~S}$ $\mathrm{ha}^{-1}$ which was at par with $40 \mathrm{~kg} \mathrm{Sha}^{-1}$ and the lowest one (31.38) was recorded in control treatment $(0 \mathrm{~kg} \mathrm{~S}$ $\mathrm{ha}^{-1}$ ). These results are in agreement with the findings of Sharma et al. (2003) who reported that increasing S rate increased the number of pods plant ${ }^{-1}$. The maximum number of seeds pod $^{-1}$ (56.67) was produced when the crop was fertilized with $30 \mathrm{~kg} \mathrm{~S}^{-1}{ }^{-1}$ which was as good as $20 \mathrm{~kg} \mathrm{~S} \mathrm{ha}{ }^{-1}$ (55.67) and the lowest one (46.33) was produced with controls. Sulphur nutrient might have stimulated metabolic energy of the plant, which enhanced the seeds pod ${ }^{-1}$ with increasing S fertilization.
Shelke et al. (2014) observed that increasing S rate resulted in a significant increase in the seeds $\operatorname{pod}^{-1}$. Numerically, the highest thousand seed weight $(2.84 \mathrm{~g})$ was found in $40 \mathrm{~kg} \mathrm{~S} \mathrm{ha}^{-1}$ followed by $50 \mathrm{~kg} \mathrm{~S} \mathrm{ha}^{-1}$ and the lowest one was recorded in $\left(0 \mathrm{~kg} \mathrm{~S} \mathrm{ha}^{-1}\right)$ control. The highest harvest index (25.83\%) was obtained from $20 \mathrm{~kg}$ $\mathrm{S} \mathrm{ha}{ }^{-1}$ which was statistically identical to the harvest index of $40 \mathrm{~kg} \mathrm{~S} \mathrm{ha}^{-1}$ and the lowest one $(22.52 \%)$ was recorded in $30 \mathrm{~kg} \mathrm{~S} \mathrm{ha}^{-1}$ (Table 2). Significant difference was found among the $\mathrm{S}$ levels in respect of seed yield. Seed yield ranged from 502.20 to $800.00 \mathrm{~kg} \mathrm{ha}^{-1}$. The highest seed yield $\left(800.00 \mathrm{~kg} \mathrm{ha}^{-1}\right)$ was obtained in 30 $\mathrm{kg} \mathrm{S} \mathrm{ha}^{-1}$ followed by $40 \mathrm{~kg} \mathrm{~S}^{-1}$ and the lowest one $\left(502.20 \mathrm{~kg} \mathrm{ha}^{-1}\right)$ was produced in control $\left(0 \mathrm{~kg} \mathrm{~S} \mathrm{ha}^{-1}\right)$. Seed yield increased due to increased level of $S$, which caused improvement of yield components. Allam (2002) reported that in a field trial, $\mathrm{S}$ fertilizer has increased yield from $20 \%$ to $42 \%$ in sesame. The highest stover yield $\left(2787.00 \mathrm{~kg} \mathrm{ha}^{-1}\right)$ was obtained in $30 \mathrm{~kg} \mathrm{~S} \mathrm{ha}^{-1}$ and the lowest one $\left(1550.00 \mathrm{~kg} \mathrm{ha}^{-1}\right)$ was found in without $\mathrm{S}$ fertilization $\left(0 \mathrm{~kg} \mathrm{~S} \mathrm{ha}^{-1}\right)$, which was at par with $10 \mathrm{~kg} \mathrm{~S}$ $\mathrm{ha}^{-1}$. Oil content ranged from $32.80 \%$ to $43.97 \%$. The highest oil content $(43.97 \%)$ was obtained in $30 \mathrm{~kg} \mathrm{~S}$ $\mathrm{ha}^{-1}$, which was followed by $40 \mathrm{~kg} \mathrm{Sha}^{-1}$ and the lowest oil content (32.80\%) was obtained in control treatment (Table 2). Similar results were reported by Choudhary et al. (2016) who stated that application of $30 \mathrm{~kg} \mathrm{~S} \mathrm{ha}^{-1}$ was significantly superior to 10 and $20 \mathrm{~kg} \mathrm{~S} \mathrm{ha}^{-1}$. The increase in oil content might be due to higher oil synthesis due to increased dose of $\mathrm{S}$.

Table 2. Effect of levels sulphur on dry matter production, crop characters, yield components, seed yield and oil content of sesame

\begin{tabular}{|c|c|c|c|c|c|c|c|c|c|c|}
\hline $\begin{array}{c}\text { Level of } \\
\text { sulphur } \\
\left(\mathrm{kg} \mathrm{S} \mathrm{ha}^{-1}\right)\end{array}$ & $\begin{array}{c}\text { Dry matter } \\
\text { production plant }^{-1} \\
\text { at } 50 \text { DAS }(\mathrm{g})\end{array}$ & $\begin{array}{c}\text { Plant height } \\
\text { at harvest } \\
(\mathrm{cm})\end{array}$ & $\begin{array}{c}\text { No. of } \\
\text { branches } \\
\text { plant }^{-1}\end{array}$ & $\begin{array}{l}\text { No. of } \\
\text { pods } \\
\text { plant }^{-1}\end{array}$ & $\begin{array}{l}\text { No. of } \\
\text { seeds } \\
\text { pod }^{-1}\end{array}$ & $\begin{array}{l}\text { 1000-seed } \\
\text { weight } \\
(\mathrm{g})\end{array}$ & $\begin{array}{c}\text { Seed } \\
\text { yield } \\
\left(\mathrm{kg} \mathrm{ha}^{-1}\right)\end{array}$ & $\begin{array}{c}\text { Stover } \\
\text { yield } \\
\left(\mathrm{kg} \mathrm{ha}^{-1}\right)\end{array}$ & $\begin{array}{c}\text { Harvest } \\
\text { index } \\
(\%)\end{array}$ & $\begin{array}{l}\text { Oil content } \\
(\%)\end{array}$ \\
\hline 0 & $8.748 \mathrm{f}$ & $90.42 d$ & $2.934 d$ & $31.38 \mathrm{f}$ & $46.33 d$ & 2.69 & $502.2 \mathrm{~d}$ & $1550.00 \mathrm{~d}$ & $24.42 b$ & $32.80 \mathrm{f}$ \\
\hline 10 & $10.71 \mathrm{e}$ & $93.47 \mathrm{c}$ & $3.337 \mathrm{c}$ & $34.07 \mathrm{e}$ & $50.00 \mathrm{c}$ & 2.70 & $531.3 \mathrm{~d}$ & $1666.00 \mathrm{~d}$ & $24.41 b$ & $35.17 \mathrm{e}$ \\
\hline 20 & $11.67 \mathrm{~d}$ & $95.58 \mathrm{c}$ & $3.380 \mathrm{c}$ & $37.07 \mathrm{~d}$ & $51.33 \mathrm{c}$ & 2.69 & $647.8 b c$ & $1822.00 \mathrm{c}$ & $25.83 \mathrm{a}$ & $37.83 \mathrm{~d}$ \\
\hline 30 & $20.81 \mathrm{a}$ & $109.7 \mathrm{a}$ & $3.867 \mathrm{a}$ & $46.13 a$ & $56.67 \mathrm{a}$ & 2.76 & $800.0 \mathrm{a}$ & $2787.00 \mathrm{a}$ & $22.52 \mathrm{c}$ & $43.97 \mathrm{a}$ \\
\hline 40 & $16.31 \mathrm{~b}$ & $101.7 b$ & $3.733 \mathrm{ab}$ & $42.56 b$ & $55.67 \mathrm{ab}$ & 2.84 & $698.7 \mathrm{~b}$ & $2088.00 \mathrm{~b}$ & $25.13 \mathrm{ab}$ & $42.87 b$ \\
\hline 50 & $13.81 \mathrm{c}$ & $99.78 \mathrm{~b}$ & $3.622 b$ & $39.98 \mathrm{c}$ & $54.33 b$ & 2.83 & $593.6 \mathrm{c}$ & $1905.00 \mathrm{c}$ & $23.86 \mathrm{~b}$ & $39.97 \mathrm{c}$ \\
\hline$S \bar{x}$ & 0.272 & 1.02 & 0.078 & 0.686 & 0.665 & 0.038 & 20.05 & 49.49 & 0.408 & 0.301 \\
\hline $\begin{array}{l}\text { Level of } \\
\text { significance }\end{array}$ & $* *$ & $* *$ & $* *$ & $* *$ & $* *$ & NS & $* *$ & $* *$ & $* *$ & $* *$ \\
\hline CV (\%) & 5.97 & 3.10 & 6.73 & 5.35 & 3.81 & 5.58 & 9.56 & 7.54 & 5.03 & 2.33 \\
\hline
\end{tabular}

In a column, figures with same letter or without letter do not differ significantly whereas figures with dissimilar letter (s) differ significantly (as per DMRT.

$* *=$ Significant at $1 \%$ level of probability. NS $=$ Not significant. 


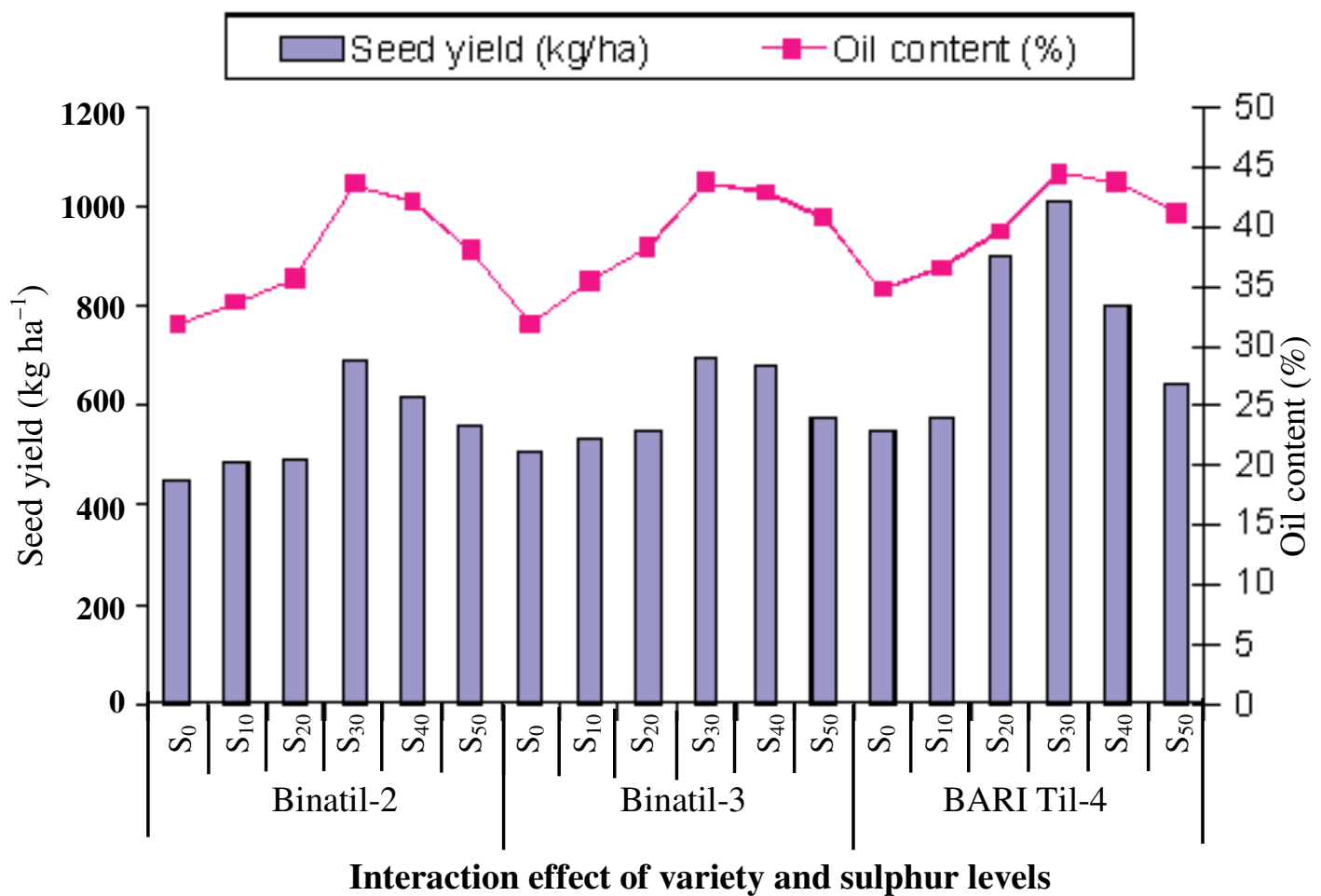

Fig. 1. Interaction effect between variety and levels of sulphur on seed yield and oil content of sesame

Interaction effect of variety and sulphur level

Interaction effect of variety and $\mathrm{S}$ level was significantly influenced dry matter production, number of seeds pod ${ }^{-1}$ and 1000-seed weight (Table 3). The highest dry matter production plant $^{-1}(24.80 \mathrm{~g})$ was produced in BARI Til-4 fertilized with $30 \mathrm{~kg} \mathrm{~S} h a^{-1}$ and the lowest one $(7.28 \mathrm{~g})$ was produced in Binatil-2 with $0 \mathrm{~kg} \mathrm{~S}^{-1}$. BARI Til-4 fertilized with $40 \mathrm{~kg} \mathrm{~S} \mathrm{ha}^{-1}$ and $50 \mathrm{~kg} \mathrm{~S} h a^{-1}$ and Binatil3 fertilized with $30 \mathrm{~kg} \mathrm{~S} \mathrm{ha}{ }^{-1}$ produced statistically identical seed yields and occupied the second position (Table 3). The interaction of variety and S level did not significantly affect plant height and number of branches plant $^{-1}$. Plant height ranged from $113.7 \mathrm{~cm}$ to $86.87 \mathrm{~cm}$. However, numerically the tallest plant $(113.7 \mathrm{~cm})$ was obtained in BARI Til-4 fertilized with $30 \mathrm{~kg} \mathrm{~S}^{-1}$ and the shortest one $(86.87 \mathrm{~cm})$ was recorded in Binatil-2 under control treatment $\left(0 \mathrm{~kg} \mathrm{~S} h^{-1}\right)$. Numerically the highest number of branches plant ${ }^{-1}$ (4.0) was produced in BARI Til-4 fertilized with $30 \mathrm{~kg} \mathrm{~S} \mathrm{ha}^{-1}$ and $40 \mathrm{~kg} \mathrm{~S}$ $\mathrm{ha}^{-1}$, and the lowest one (2.73) was produced in Binatil-2 under control treatment. BARI Til-4 fertilized with 30 $\mathrm{kg} \mathrm{S} \mathrm{ha}{ }^{-1}$ resulted maximum number of pods plant ${ }^{-1}$ (51.13) which was at par with BARI Til-4 fertilized with $40 \mathrm{~kg} \mathrm{~S} h a^{-1}$ and Binatil-3 fertilized with $30 \mathrm{~kg} \mathrm{~S} \mathrm{ha}^{-1}$. Number of seeds $\operatorname{pod}^{-1}$ (62.00) was the highest in BARI Til-4 fertilized with $30 \mathrm{~kg} \mathrm{~S} \mathrm{ha}^{-1}$ which was at par with combined effect of BARI Til-4 fertilized with 40, 20 and $10 \mathrm{~kg} \mathrm{~S} \mathrm{ha}^{-1}$. The lowest number of pods plant ${ }^{-1}$ (28.07) and seeds $\operatorname{pod}^{-1}$ (39.00) were produced in Binatil-2 with control. The highest 1000 -seed weight (3.28 g) was produced in Binatil-2 fertilized with $50 \mathrm{~kg} \mathrm{~S} \mathrm{ha}^{-1}$ which was as good as Binatil-2 fertilized with $30 \mathrm{~kg} \mathrm{~S}^{-1}$ $(2.94 \mathrm{~g})$ and the lowest one $(2.53 \mathrm{~g})$ was obtained in BARI Til-4 fertilized with $50 \mathrm{~kg} \mathrm{~S} \mathrm{ha}{ }^{-1}$. The highest seed yield $\left(1011.00 \mathrm{~kg} \mathrm{ha}^{-1}\right)$ was obtained in BARI Til-4 fertilized with $30 \mathrm{~kg} \mathrm{~S}^{-1}$ which was followed by BARI Til-4 fertilized with $20 \mathrm{~kg} \mathrm{~S} \mathrm{ha}^{-1}$ while the lowest seed yield $\left(449.30 \mathrm{~kg} \mathrm{ha}^{-1}\right)$ was obtained in Binatil-2 under control treatment (Table 3). The highest stover yield was found in BARI Til-4 (3751.00 $\left.\mathrm{kg} \mathrm{ha}^{-1}\right)$ fertilized with $30 \mathrm{~kg} \mathrm{~S} h a^{-1}$. Stover yield of Binatil-3 and Binatil-2 were statistically identical when fertilized with $30 \mathrm{~kg} \mathrm{~S} \mathrm{ha}{ }^{-1}$. The lowest stover yield was recorded in Binatil-2 under control treatment $\left(0 \quad \mathrm{~kg}^{\mathrm{S}} \mathrm{ha}^{-1}\right)$. Significant influence on harvest index was found in the interaction effect of variety and $\mathrm{S}$ level. The highest harvest index (31.42\%) was obtained in BARI Til-4 fertilized with $20 \mathrm{~kg} \mathrm{~S}$ ha-1, which was followed by Binatil-2 fertilized with $40 \mathrm{~kg} \mathrm{~S}$ ha-1 while the lowest harvest index (21.21\%) was obtained in BARI Til-4 fertilized with $30 \mathrm{~kg} \mathrm{~S} \mathrm{ha}^{-1}$. The highest oil content was found in BARI Til-4 (44.50\%) fertilized with $30 \mathrm{~kg} \mathrm{~S}$ $\mathrm{ha}^{-1}$, which was as good as BARI Til-4 fertilized with 40 $\mathrm{kg} \mathrm{S} \mathrm{ha}^{-1}$. The oil content of Binatil-3 and Binatil-2 were statistically identical when fertilized with $30 \mathrm{~kg} \mathrm{~S} \mathrm{ha}^{-1}$, while the lowest oil content was obtained in Binatil-2 under control treatment (no S fertilization) (Fig. 1). 
Table 3. Effect of interaction between variety and levels of sulphur on crop characters, yield contributing characters and harvest index of sesame

\begin{tabular}{|c|c|c|c|c|c|c|c|c|c|c|}
\hline $\begin{array}{c}\text { Interaction } \\
\text { (Variety } \times \text { Level } \\
\text { of sulphur) }\end{array}$ & $\begin{array}{c}\text { Dry matter } \\
\text { production plant } \\
{ }^{-1} \\
\text { at } 50 \text { DAS }(\mathrm{g})\end{array}$ & $\begin{array}{c}\text { Plant } \\
\text { height } \\
(\mathrm{cm})\end{array}$ & $\begin{array}{c}\text { No. of } \\
\text { branches } \\
\text { plant }^{-1}\end{array}$ & $\begin{array}{l}\text { No. of } \\
\text { pods } \\
\text { plant }^{-1}\end{array}$ & $\begin{array}{l}\text { No. of } \\
\text { seeds } \\
\text { pod }^{-1}\end{array}$ & $\begin{array}{l}\text { 1000- seed } \\
\text { weight }(\mathrm{g})\end{array}$ & $\begin{array}{c}\text { Seed yield } \\
\left(\mathrm{kg} \mathrm{ha}^{-1}\right)\end{array}$ & $\begin{array}{c}\text { Stover yield } \\
\left(\mathrm{kg} \mathrm{ha}^{-1}\right)\end{array}$ & $\begin{array}{c}\text { Harvest } \\
\text { index }(\%)\end{array}$ & $\begin{array}{c}\text { Oil } \\
\text { content } \\
(\%)\end{array}$ \\
\hline $\mathrm{V}_{1} \times \mathrm{S}_{0}$ & $7.28 \mathrm{i}$ & 86.87 & 2.73 & $28.07 \mathrm{~h}$ & $39.00 \mathrm{~h}$ & 2.86bcd & $449.30 \mathrm{i}$ & $1470.00 \mathrm{~g}$ & 23.38defghi & $31.80 \mathrm{k}$ \\
\hline $\mathrm{V}_{1} \times \mathrm{S}_{10}$ & $8.05 \mathrm{hi}$ & 88.80 & 3.27 & $32.13 \mathrm{~g}$ & $40.00 \mathrm{~h}$ & $2.89 \mathrm{bcd}$ & $486.00 \mathrm{hi}$ & $1493.00 \mathrm{~g}$ & 24.56cdef & $33.60 \mathrm{j}$ \\
\hline $\mathrm{V}_{1} \times \mathrm{S}_{20}$ & $8.22 \mathrm{ghi}$ & 90.20 & 3.27 & 34.80defg & $41.00 \mathrm{~h}$ & $2.88 \mathrm{bcd}$ & $490.00 \mathrm{hi}$ & $1553.00 \mathrm{~g}$ & 23.99defg & $35.70 \mathrm{hi}$ \\
\hline $\mathrm{V}_{1} \times \mathrm{S}_{30}$ & $17.46 \mathrm{c}$ & 102.6 & 3.80 & $38.00 \mathrm{cde}$ & $50.00 \mathrm{fg}$ & $2.94 \mathrm{ab}$ & $691.30 \mathrm{~d}$ & $2218.00 \mathrm{bc}$ & 23.76defgh & $43.60 \mathrm{a}$ \\
\hline $\mathrm{V}_{1} \times \mathrm{S}_{40}$ & $11.27 \mathrm{e}$ & 100.0 & 3.60 & $37.33 \mathrm{cdef}$ & $49.00 \mathrm{~g}$ & $2.79 \mathrm{bcd}$ & 614.70defg & $1894.00 \mathrm{de}$ & $27.19 b$ & $42.00 \mathrm{bc}$ \\
\hline $\mathrm{V}_{1} \times \mathrm{S}_{50}$ & $10.92 \mathrm{ef}$ & 99.33 & 3.53 & $37.00 \mathrm{def}$ & $48.00 \mathrm{~g}$ & $3.28 \mathrm{a}$ & $558.70 \mathrm{fghi}$ & $1667.00 \mathrm{efg}$ & $25.10 \mathrm{bcde}$ & $38.00 \mathrm{fg}$ \\
\hline $\mathrm{V}_{2} \times \mathrm{S}_{0}$ & $9.47 \mathrm{fgh}$ & 88.93 & 2.80 & $32.40 \mathrm{~g}$ & $49.00 \mathrm{~g}$ & $2.65 \mathrm{bcd}$ & $510.00 \mathrm{ghi}$ & $1575.00 \mathrm{~g}$ & 24.46cdefg & $31.80 \mathrm{k}$ \\
\hline $\mathrm{V}_{2} \times \mathrm{S}_{10}$ & $9.57 \mathrm{fg}$ & 95.07 & 3.27 & $34.40 \mathrm{efg}$ & $51.00 \mathrm{fg}$ & $2.67 \mathrm{bcd}$ & $529.30 \mathrm{ghi}$ & 1655.00efg & 24.24defg & $35.40 \mathrm{hi}$ \\
\hline $\mathrm{V}_{2} \times \mathrm{S}_{20}$ & $10.25 \mathrm{ef}$ & 97.20 & 3.40 & $37.93 \mathrm{cde}$ & $53.00 \mathrm{ef}$ & $2.65 \mathrm{bcd}$ & 550.70 fghi & $1942.00 \mathrm{~cd}$ & $22.09 \mathrm{ghi}$ & $38.20 \mathrm{ef}$ \\
\hline $\mathrm{V}_{2} \times \mathrm{S}_{30}$ & $20.18 b$ & 112.8 & 3.80 & $49.27 \mathrm{a}$ & $58.00 \mathrm{bcd}$ & $2.68 \mathrm{bcd}$ & $698.00 \mathrm{~d}$ & $2392.00 \mathrm{~b}$ & 22.59fghi & $43.80 \mathrm{a}$ \\
\hline $\mathrm{V}_{2} \times \mathrm{S}_{40}$ & $17.01 \mathrm{c}$ & 102.3 & 3.60 & $41.87 \mathrm{~b}$ & $57.00 \mathrm{~cd}$ & $2.90 \mathrm{bc}$ & $682.00 \mathrm{de}$ & $2175.00 \mathrm{bc}$ & $21.52 \mathrm{hi}$ & $42.90 \mathrm{ab}$ \\
\hline $\mathrm{V}_{2} \times \mathrm{S}_{50}$ & $11.11 \mathrm{e}$ & 99.73 & 3.60 & $41.00 \mathrm{bc}$ & $55.00 \mathrm{de}$ & $2.67 \mathrm{bcd}$ & 577.3efgh & $1961.00 \mathrm{~cd}$ & 22.75efghi & $40.80 \mathrm{~cd}$ \\
\hline $\mathrm{V}_{3} \times \mathrm{S}_{0}$ & 9.49fgh & 95.47 & 3.27 & $33.67 \mathrm{fg}$ & $51.00 \mathrm{fg}$ & $2.57 \mathrm{~cd}$ & 547.30fghi & $1605.00 \mathrm{fg}$ & $25.43 \mathrm{bcd}$ & $34.80 \mathrm{ij}$ \\
\hline $\mathrm{V}_{3} \times \mathrm{S}_{10}$ & $14.50 \mathrm{~d}$ & 96.53 & 3.47 & 35.67defg & $59.00 \mathrm{abc}$ & $2.55 \mathrm{~cd}$ & 578.70 efgh & $1852.00 \mathrm{def}$ & $24.42 \mathrm{cdefg}$ & $36.50 \mathrm{gh}$ \\
\hline $\mathrm{V}_{3} \times \mathrm{S}_{20}$ & $16.55 \mathrm{c}$ & 99.33 & 3.47 & $38.47 \mathrm{bcd}$ & $60.00 \mathrm{abc}$ & $2.55 \mathrm{~cd}$ & $902.70 \mathrm{~b}$ & $1971.00 \mathrm{~cd}$ & $31.42 \mathrm{a}$ & $39.60 \mathrm{de}$ \\
\hline $\mathrm{V}_{3} \times \mathrm{S}_{30}$ & $24.80 \mathrm{a}$ & 113.7 & 4.00 & $51.13 \mathrm{a}$ & $62.00 \mathrm{a}$ & 2.6 & & & 21 & $44.50 \mathrm{a}$ \\
\hline $\mathrm{V}_{3} \times \mathrm{S}_{40}$ & $20.64 \mathrm{~b}$ & 102.7 & 4.00 & $48.47 \mathrm{a}$ & $61.00 \mathrm{ab}$ & $2.78 \mathrm{bcd}$ & $799.30 \mathrm{c}$ & $2195.00 \mathrm{bc}$ & $26.69 \mathrm{bc}$ & $43.70 \mathrm{a}$ \\
\hline $\mathrm{V}_{3} \times \mathrm{S}_{50}$ & $19.40 \mathrm{~b}$ & 100.3 & 3.73 & $41.93 \mathrm{~b}$ & $60.00 \mathrm{abc}$ & $2.53 \mathrm{~d}$ & $644.70 \mathrm{def}$ & $2086.00 \mathrm{~cd}$ & $23.73 \mathrm{defgh}$ & $41.10 \mathrm{~cd}$ \\
\hline$S \bar{x}$ & 0.47 & 1.76 & 0.135 & 1.19 & 1.15 & 0.054 & 34.73 & 85.73 & 0.707 & 0.522 \\
\hline $\begin{array}{l}\text { Level of } \\
\text { significance }\end{array}$ & $* *$ & NS & NS & $* *$ & $* *$ & $*$ & $* *$ & $* *$ & $* *$ & $*$ \\
\hline $\mathrm{CV}(\%)$ & 5.97 & 3.10 & 6.73 & 5.35 & 3.81 & 5.58 & 9.56 & 7.54 & 5.03 & 2.33 \\
\hline
\end{tabular}

In a column, figures with same letter or without letter do not differ significantly whereas figures with dissimilar letter (s) differ significantly (as per DMRT).

$* *=$ Significant at $1 \%$ level of probability, $*=$ Significant at $5 \%$ level of probability, NS $=$ Not significant $\mathrm{V}_{1}=$ Binatil-2; $\mathrm{V}_{2}=$ Binatil-3; $\mathrm{V}_{3}=$ BARI Til-4 $\mathrm{S}_{0}=0 \mathrm{~kg} \mathrm{~S}, \mathrm{~S}_{10}=10 \mathrm{~kg} \mathrm{~S}, \mathrm{~S}_{20}=20 \mathrm{~kg} \mathrm{~S}, \mathrm{~S}_{30}=30 \mathrm{~kg} \mathrm{~S}, \mathrm{~S}_{40}=40 \mathrm{~kg} \mathrm{~S}, \mathrm{~S}_{50}=50 \mathrm{~kg} \mathrm{~S}$.

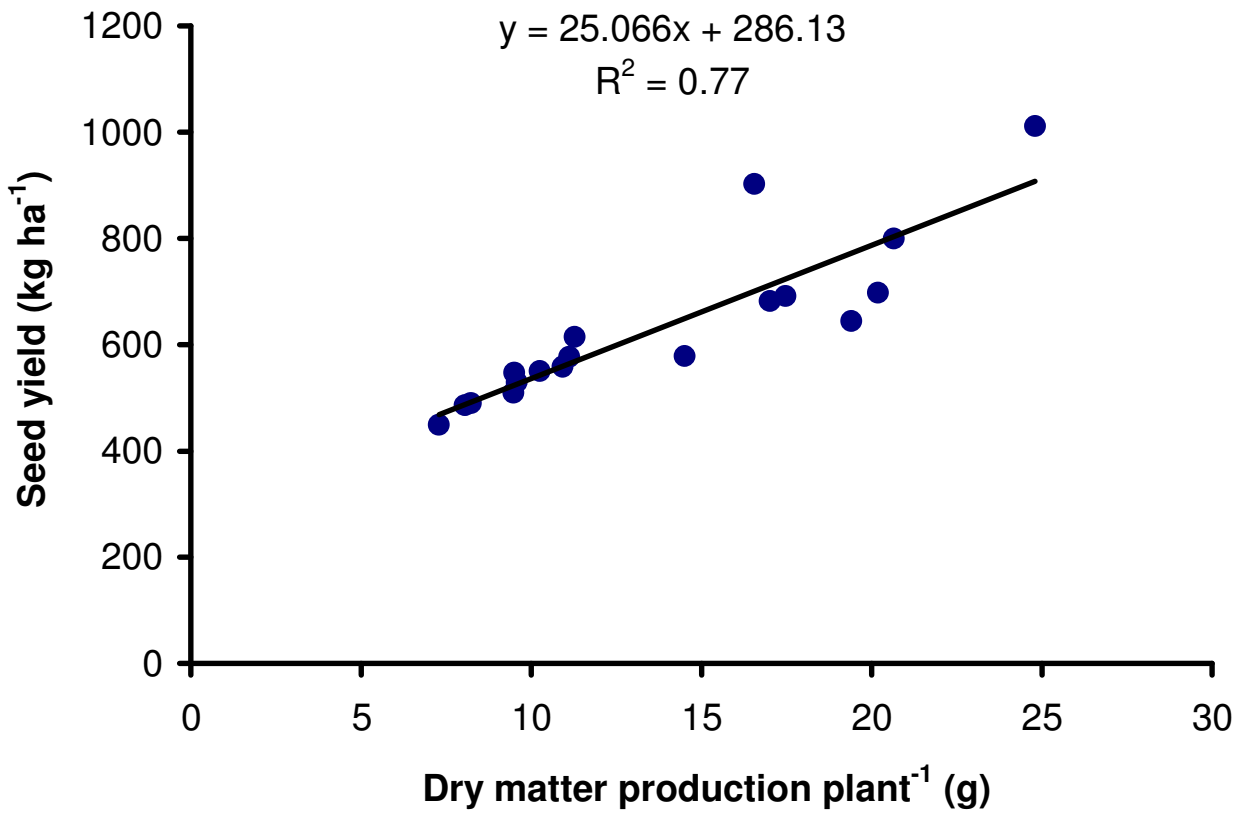

Fig. 2. Functional relationship between total dry matter production at $50 \mathrm{DAS}$ and seed yield of sesame

Functional relationship between total dry matter production at 50 DAS and seed yield of sesame

Total dry matter production is an important parameter for the determination of seed yield of sesame (Akter $e t$ al., 2016). Partitioning of dry matter in sink organs, i.e. seeds are responsible for the seed yield of sesame. The relationship of total dry matter production at 50 DAS and seed yield of sesame was determined by using the interaction data between variety and level of $S$ application. Experimental results revealed that seed yield showed significantly positive correlation with total dry matter production at 50 DAS (Fig. 2). The functional relationship was significant at $p \leq 0.01$. The functional relationship can be determined by the regression equation $\mathrm{Y}=25.066 \mathrm{x}+286.13\left(\mathrm{R}^{2}=0.77\right)$. It was revealed that $77 \%$ of the variation in yield could be explained from the variation in total dry matter production at 50 DAS. This means an increase in total 
dry matter production will result in the corresponding increase in the seed yield of sesame. This indicates that total dry matter production might be a critical characteristic feature for seed yield performance of sesame.

\section{Conclusion}

Under the perspective of present experimentation, all the varieties of sesame included in the study exhibited an increasing trend in seed yield and oil content with increased level of $\mathrm{S}$ from $0 \mathrm{~kg}$ to $30 \mathrm{~kg} \mathrm{ha}^{-1}$. BARI Til-4 produced the highest seed yield and oil content (\%) when fertilized with $30 \mathrm{~kg} \mathrm{~S} \mathrm{ha}^{-1}$ followed by Binatil-3 and Binatil-2. Still the latter two varieties may express their promising performance in other location specific differential environmental conditions. In this study BARI Til-4 fertilized with $30 \mathrm{~kg} \mathrm{~S} \mathrm{ha}{ }^{-1}$ appears as a promising practice in respect of seed yield and oil content of sesame in Bangladesh. Therefore, sesame growers can be select BARI Til-4 along with $30 \mathrm{~kg} \mathrm{~S}$ $\mathrm{ha}^{-1}$ for maximizing yield and oil content.

\section{References}

Ajai Singh, S. P., Singh, R. S., Katiyar and Singh, P. P. 2000. Response of nitrogen and sulphur on economic yield of sunflower under sodic soil condition. Indian Journal of Agricultural Sciences, 70: 536-537.

Allam, A. Y. 2002. Effect of gypsum, nitrogen fertilization and hill spacing on seed and oil yields of sesame cultivated on sandy soil. Assiut Journal of Agricultural Sciences, 33(4): $1-6$.

Akter, M., Khaliq, Q. A., Islam, M. R. and Ahmed, J. U. 2016. Photosynthesis, dry matter partitioning and yield variation in sesame genotypes. Bangladesh Agronomy Journal, 19(1): 19-28. https://doi.org/10.3329/baj.v19i1.29865

Akinoso, R, Aboaba, S. A. and Olayanju, T. M. A. 2010. Effects of moisture content and heat treatment on peroxide value and oxidation stability of un-refined sesame oil. African Journal of Food, Agriculture, Nutrition and Development, 10(10): $4268-4285$. https://doi.org/10.4314/ajfand.v10i10.62908

BBS. 2015. Bangladesh Bureau of Statistics, Stat. Div., Minist. Planning, Govt. People's Repub. of Bangladesh, Dhaka, Bangladesh.

BBS. 2017. Bangladesh Bureau of Statistics, Stat. Div., Minist. Planning, Govt. People's Repub. of Bangladesh, Dhaka, Bangladesh.

Choudhary, A. A., Nikam, R. R. and Patil, S. S. 2016. Effect of Phosphorus and Sulphur on Oil, Nutrient Uptake and Yield of Linseed. International Journal of Life Sciences, A6: 33-36.
El Naim, A. M., El dey, E. M., Jabereldar, A. A., Ahmed, S. E. and Ahmed, A. A. 2012. Determination of suitable variety and seed rate of sesame (Sesamum indicum L.) in sandy dunes of Kordofan, sudan. International Journal of Agriculture and Forestry. 2 (4): 175-179.

Gomez, K. A. and Gomez, A. A. 1984. Statistical Procedure for Agril. Res. John Willey and Sons, New York. pp . 28-92.

Khan, M. A. H., Sultan, N. A., Islam, M. N. and Hasanuzzaman, M. 2009. Yield and contributing characters of sesame as affected by different management practices. AmericanEurasian Journal of Scientific Research, 4(3): 195-197.

Khan, N., Khalil, S. K., Amanullah, Ali, A., Ullah, Z. and Ali, M. 2016. Effect of nitrogen and sulfur on yield and yield components of sesame (Sesamum indicum $\mathrm{L}$.) in calcareous soil. Pure and Applied Biology, 5(3): 471-475. https://doi.org/10.19045/bspab.2016.50061

Kundu, C. K., Mondal, S. Basu, B. and Bandopadhyay, P. 2010. Effect of doses and time of sulphur application on yield and oil content of sesame (Sesamum indicum L.). Environment and Ecology, 28(4A): 2629-2631.

Miah, M. A. M., Afroz, A., Rashid, M. A. and Shiblee, S. A. M. 2015. Factors affecting adoption of improved sesame technologies in some selected areas in Bangladesh. The Agriculturists, 13(1): 140-151.

Mohsana, A. 2009. Effect of different levels of sulphur and boron on the yield and oil content of sesame. M.S. Thesis. Dept. Agron. Bangladesh Agril. Univ. Mymensingh p. 43-48.

Nagwani, A. V., Chandrika, S. and Muneendra, S. 2001. Effect of nitrogen and sulphur of yield and oil content of sesame. Journal of Oilseed Research, 18: 73-77.

Obaidul, H. 2012. Effect of sulphur and boron on seed yield of sesame (Sesamum indicum L.) M. S. Thesis. Dept. of Agron. Bangladesh Agril. Univ. Mymensingh p. 24-34.

Patel, J. R. and Shelke, V. B. 1995. Effect of farmyard manure, phosphorus and sulphur on growth, yield and quality of Indian mustard. Indian Journal of Agronomy, 43: 713-717.

Raja, A. Hattab, O. K., Gurusamy, L. and Suganya, S. 2007. Sulphur levels on nutrient uptake and yield of sesame varieties and nutrient availability. International Journal of Soil Science, 2: $278-285$. https://doi.org/10.3923/ijss.2007.278.285

Sarkar, R. K. and Banik, P. 2002. Effect of planting geometry, direction of planting and sulphur application on growth and productivity of sesame (Sesamum indicum). Indian Journal of Agricultural Science, 72(2) : 70-73.

Sharma, H. R. and Gupta, A. K. 2003. Effect of sulphur on growth parameters and yield of some selected crops. Annals of Agricultural Research, 24(1): 136-138.

Shelke, R. I., Kalegore, N. K. and Wayase, K. P. 2014. Effect of levels of phosphorus and sulphur on growth, yield and quality of sesame (Sesamum indicum L.). World Journal of Agricultural Sciences, 10(3): 108-11.

Singh, M. L. G. and Anant, N. K. 1960. Effect of N, P and S on the yield and oil content of sesame. Indian Journal of Agronomy, 4:176-181.

Tiwari, K. N. and Gupta, B. R. 2006. Sulphur for sustainable high yield Agriculture in Uttar Pradesh. Indian Journal of Fertilizer, 1: 37-52. 